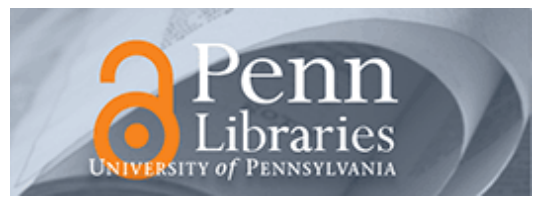

University of Pennsylvania ScholarlyCommons

\title{
$5-1997$
}

\section{Incumbent Defense Strategies Against New Product Entry}

Hubert Gatignon

INSEAD

Thomas S. Robertson

University of Pennsylvania

Adam J. Fein

University of Pennsylvania

Follow this and additional works at: https://repository.upenn.edu/mgmt_papers

Part of the Management Sciences and Quantitative Methods Commons

\section{Recommended Citation}

Gatignon, H., Robertson, T. S., \& Fein, A. J. (1997). Incumbent Defense Strategies Against New Product Entry. International Journal of Research in Marketing, 14 (2), 163-176. http://dx.doi.org/10.1016/ S0167-8116(96)00035-3

This paper is posted at ScholarlyCommons. https://repository.upenn.edu/mgmt_papers/258

For more information, please contact repository@pobox.upenn.edu. 


\title{
Incumbent Defense Strategies Against New Product Entry
}

\author{
Abstract \\ posed by the new product entry. \\ Keywords \\ retaliation, competitive response, innovative entry, reaction speed \\ Disciplines \\ Management Sciences and Quantitative Methods
}

The objective of this study is to estimate the effectiveness of different defense strategies when faced with a new product introduction by a competitor. Using a sample of in cumbentsacross a wide range of industries, we find that faster reactions to the new entrant have a positive impact on the perceived success of the defense strategy. However, the greater the breadth of reaction (number of marketing mix instruments used), the less successful is the defense. The ability of an incumbent to maintain its market position is also significantly affected by industry characteristics and the degree of competitive threat 


\title{
INCUMBENT DEFENSE STRATEgIES \\ AgAINST NEW Product ENTRY
}

by

\author{
HUbert Gatignon* \\ THOMAS S. ROBERTSON**
}

$\boldsymbol{\&}$

ADAM J. FEIN $\dagger$

95/49/MKT

* Professor of Marketing, at INSEAD, Boulevard de Constance, Fontainebleau 77305 Cedex, France.

** Sainsbury Professor of Marketing at the London Business School.

$\dagger$ Doctoral Candidate at the Wharton School of the University of Pennsylvania.

A working paper in the INSEAD Working Paper Series is intended as a means whereby a faculty researcher's thoughts and findings may be communicated to interested readers. The paper should be considered preliminary in nature and may require revision.

Printed at INSEAD, Fontainebleau, France 


\author{
Hubert Gatignon
}

Thomas S. Robertson

and

Adam J. Fein

June 1995

Hubert Gatignon is Professor of Marketing at INSEAD, Thomas S. Robertson is the Sainsbury Professor of Marketing at the London Business School, and Adam Fein is a Doctoral Candidate at the Wharton School of the University of Pennsylvania.

Please send all correspondance to:

Hubert Gatignon

Professor of Marketing

INSEAD

Boulevard de Constance

77305 Fontainebleau Cedex

Tel: (33) (1) 60-72-40-00

Fax: (33) (1) 60-72-42-42

e:mail: GATIGNON@INSEAD.FR 


\section{INCUMBENT DEFENSE STRATEGIES AGAINST NEW PRODUCT ENTRY}

\section{Abstract}

The objective of this study is to estimate the effectiveness of different defense strategies when faced with a new product introduction by a competitor. Using a sample of incumbents across a wide range of industries, we find that faster reactions to the new entrant have a positive impact on the perceived success of the defense strategy. However, the greater the breadth of reaction (number of marketing mix instruments used), the less successful the defense. The ability of an incumbent to maintain its market position is also significantly affected by industry characteristics and the degree of competitive threat posed by the entrant. 


\section{INCUMBENT DEFENSE STRATEGIES AGAINST NEW PRODUCT ENTRY}

The focus of this research is on the defense strategies that incumbents use when confronted with new competitive products. The goal is to explain the success of reaction strategies, rather than to explain the likelihood of reaction, which is the more prevalent research objective in the extant literature. In other words our concern is not with whether incumbents react, but given that they react, how successful will their responses be? In particular, are faster responses likely to be more successful? Which marketing instruments should be used? Are broad responses (in terms of number of marketing mix instruments) more successful than narrow responses?

The issue of market defense has considerable managerial relevance. In general, as the success of incumbents increases within a product category, the likelihood of new entry increases and with it the need for incumbents to defend their position. In many firms, however, the bias is to develop elaborate new product launch plans but seldom to proactively specify defense plans in advance of a competitive threat (Bazerman and Carroll 1987, Robertson and Gatignon 1991).

The bottom line question for managers is what defense strategies will be most effective. More specifically, the question is what responses will be most successful given a certain set of product category characteristics and the nature of the competitive threat. It is these managerial questions which have motivated the research endeavor.

We first develop a conceptual framework for structuring the determinants of a successful defense strategy, especially concerning the characterization of reaction strategies. Hypotheses are developed as part of this conceptualization. The survey used to collect the data is then described and the measures are defined. Finally, the model used to test the hypotheses is presented prior to the discussion of the results. 


\section{A Conceptualization of the Determinants of Successful Defense Strategies}

Competitive defense is the basis of a rich stream of research in the economics, strategy and marketing literatures. Most of this literature is theoretical or game-theory based, especially in economics. Recently, however, an empirical base has been developing, as we will discuss.

The economics literature on market defense has been concerned traditionally with entry deterrence and the role of price (Milgrom and Roberts 1982). More recently, the focus has extended to consider competitive interactions more broadly (Caves 1984), including technological interplay among competitors (Cohen and Levin 1989; Tushman and Nelson 1990; Gilbert 1992). Within the strategy literature a considerable body of conceptual logic has emerged regarding competitive interplay (Porter 1980, 1985). An empirical base also has been developing, which tends to be industry and case study-based (Smith, Grimm, Chen and Gannon 1991; Chen and MacMillan 1992). Within the marketing literature, the approaches to the study of competitive defense range from the work on reaction matrices of Lambin, Naert and Bultez (1975), Hanssens (1980) and, more recently, Leeflang and Wittink (1992), to the analytical normative approach of Hauser and Shugan (1983), to the PIMS approaches of Robinson (1988), Bowman and Gatignon (1995) and Ramaswamy, Gatignon and Reibstein (1994).

Whereas the existing literature is concerned mainly with the likelihood or type of reaction, our particular focus is on the success of the firm's reaction strategy. We seek to explain the incumbent firm's perception of how successful it was in retaining sales volume and market share when challenged by a new competitive product in the marketplace. 
The conceptualization which we offer to explain the success of an incumbent's defense against a new competitive product encompasses three overall categories of variables. The first set is composed of the response variables - particularly speed and the type of reaction. We examine the success of the incumbent firm's defense against a new competitive product based on how quickly the firm reacts and how it reacted. The second set comprises the milieu of product category characteristics. The variables of interest are the growth level of the product category and the technological intensity of the product category. The third set of variables characterizes the competitive threat. Specifically, we examine how success of response is affected by the incumbent's relative marketing advantage, the new competitor's relative price vs. the incumbent, and the new competitive product's relative innovativeness vs. the incumbent's product.

\subsection{Response Variables}

Competitive response to a new product can be characterized along a number of dimensions. For our purposes the focus is on three primary dimensions: (1) the speed of the response, (2) the marketing mix instrument used (e.g., lower price, increased advertising, or new product introduction) and (3) the breadth of reaction, i.e., the number of different marketing mix instruments utilized. We recognize that it could also be interesting to assess whether the response occurred in a different domain than where threatened, for example, in another market or in another product category. In our pilot research (with fifty executive education participants), however, we found the incidence of alternative domain reactions to be almost non-existent and so we did not pursue this issue further at this time. 


\subsubsection{Speed of Reaction. Interestingly, the current management literature is replete with}

admonitions to embrace speed as a business philosophy. Much of this literature is focused on the speed (cycle time) of new product development (Smith and Reinertsen 1991; Millson, Raj and Wilemon 1992; Brown and Karagozoglu 1993) or the value of early market entry and penetration (Vessey 1991; Robertson 1993). More abstractly, speed is also espoused as an overall philosophy for running the business (Stalk 1988; Eisenhardt 1990; Clark and Wheelwright 1993). Nevertheless, very little empirical evidence is offered to support the generalized value of speed. This general view suggests our first hypothesis which we discuss in the specific context of competitive responses:

\section{$H_{1} \quad$ Speed of reaction is positively related to success of reaction.}

The value of speed in responding to new competitors has been tested in a rather limited manner. Smith, Grimm, Chen and Gannon (1991), for example, in a highly constrained sample of 22 top-level managers in electronics' firms, documented a positive correlation between speed of response to competitive "critical incidents" and performance (assessed by sales growth and profits). However, they did not sort-out the causal relationships, i.e., did speed of response lead to high performance or do high performance firms respond more quickly?

In a second study in the U.S. airline industry, the same authors utilized published data on actions and reactions among industry participants to test for a relationship between speed of response to various types of actions, such as price cuts and market entry, and performance (measured as net after tax profit rate) (Smith, Grimm, Gannon and Chen 1991). A major caveat is that this study is not measuring profitability as a consequence of the reaction, but is simply looking at secondary data on the firm's general level of profitability. The authors documented a significant negative relationship (contrary to their expectations) between 
response time and performance, i.e., the slower the firm's reaction to a competitive move, the better the profitability. Although this seems to suggest that a delaying response will be more successful, it may simply reflect the fact that dominant profitable competitors feel less need to respond.

A possible explanation for the inconsistency in findings of the latter two studies is offered by Chen and MacMillan (1992), who examined the role of market dependence in affecting likelihood and speed of response in the U.S. airline industry to a composite of competitive moves, such as price cuts, service improvements, and mergers. Their findings suggest that market dependence has a significant positive main effect on likelihood of reaction. However, there is a tendency for such reactions to be slower and more cautious: ". . when attacked in their key markets, competitors . . tend to act with determination but also with deliberation and caution, for fear of precipitating escalation" (p. 564).

Thus, the strategy literature, which examines the determinants of response time, has identified a number of firm and industry factors that are associated with reaction speed in existing markets. The market pioneer literature (e.g., Lambkin 1988, Robinson 1988a, Robinson and Fornell 1985, Urban et al. 1986), which conceptualizes a faster response as lower numerical order of entry, finds that earlier entry has a positive influence on long-term market share. However, neither of these research streams provides a theoretical linkage between the speed of reaction to new entrants and the success of an incumbent. The logic for speed relating positively to the success of reaction rests in both consumer behavior and competitive behavior arguments. We propose that a faster reaction is more successful due both to its influence on consumer preference formation and to its potential signaling value. Consumer preferences are dynamic (Bettman 1979) and are often driven by earlier entrants. Carpenter and Nakamoto (1989) demonstrate that order of entry influences 
consumer preferences. In their experiments the pioneer is able to define the attributes that are valued by buyers. This advantage, however, is only conferred when the attribute space is fixed. An innovative entrant may be able to enlarge or redimensionalize attribute space through access to newer technology or by shifting the bases of competition. The entrant then has the opportunity to redefine the buyer's ideal point.

A quick reaction by the incumbent blunts this potential late-mover advantage. By acting quickly, the incumbent limits the new competitor's ability to reshape preferences. A speedy response also limits any association between the new entrant and a revised ideal point. AT\&Ts rapid response to MCr's entry into the long-distance collect calling market illustrates the value of a rapid response (Sellars 1994). MCI, taking advantage of new computer and satellite technology, was able to offer a new 800 -number collect calling service. Within two months, AT\&T responded by introducing a service with a similar name and virtually identical positioning. Although MCI altered the basis of competition in the formerly monopolistic collect calling market, AT\&T effectively blunted the advantage by "co-pioneering" the new location in product attribute space. Rapid response also lowers the likelihood of consumer trial of new product alternatives. The introduction of a competitive entry can be a source of consumer conflict and put fixed response patterns (habits) at risk (Bettman 1979). If loyalty patterns are broken, they may be difficult for the incumbent to reestablish.

In the competitive realm, speed sends a signal of commitment and an unwillingness to relinquish sales (Heil and Robertson 1991). If a faster reaction represents a credible and clear signal about the incumbent's intentions, then speed of reaction should be positively associated with success. The effect is in both the action and the signaling value of the rapid response. 1.1.2. Marketing mix instrument used to react. We now focus on the impact of the type of marketing mix reaction on the market success of the incumbent. Specifically, which marketing 
mix instruments will be most effective - product reaction, pricing reaction, or advertising/salesforce/channel reaction? Biggadike (1979) and Robinson (1988a) conclude that a lack of reaction by incumbents is the norm. When reaction does occur, it is most prevalent on price, whereas increased marketing expenditures and product changes are less likely (Robinson 1988a). This evidence, however, is based on entries corresponding to start$u p$ businesses. The high level of uncertainty associated with these businesses could lead to a cautionary attitude on the part of the incumbents which hinders response. In fact, Bowman and Gatignon (1995) found a significantly higher level of reaction when the database was not limited to start-up businesses: $60.2 \%$ of the incumbents responded to a new product introduction.

The basis for formulating hypotheses as to how the type of reaction affects performance is limited. Robertson and Gatignon (1991) have proposed a number of generalizations but provide no empirical support. They suggest that aggressive pricing is appropriate if the market is price sensitive, cross elasticity of demand is high, and economies of scale strongly affect profitability. Of course, the limit pricing literature in economics has documented the role of aggressive pricing in discouraging entry, but this is a somewhat different issue because it concerns the attempts by existing competitors to prevent rather than to react to entries (Caves and Porter 1977; Milgrom and Roberts 1982). Robertson and Gatignon (1991) further advocate innovation or extended product positioning and repositioning when threatened. They argue, in line with the classic work of Bain (1956), that increasing advertising and salesforce expenditures can act as a substantial barrier to entry.

Within the marketing literature, the work of Hauser and Shugan (1983) has been influential in specifying profit maximizing defensive strategies to new product entry. Their analytic model is of normative value but is based on a specific set of assumptions, including a 
specifiable multiattribute brand space, utility maximization by the consumer, consumer heterogeneity, and the ability to model awareness and product availability as a function of advertising and distribution. This yields some interesting recommendations, particularly that incumbent profits will be maximized upon new entry if awareness advertising is decreased and the distribution budget is decreased. The best pricing defense can be to increase price in segmented markets (Hauser 1986). While this is the profit maximizing position, Hauser and Shugan conclude that profit is always decreased by a competitive new brand. The consumer model has been tested empirically (Hauser and Gaskin 1984) and the DEFENDER model has been applied to a number of managerial situations (Hauser 1988). However, the results might depend on market conditions. For example, Kumar and Sudharshan (1988), in one of the few extensions to the DEFENDER model, find that if the market size increases due to entry, the incumbent's advertising and distribution expenditures should be increased.

Gatignon, Anderson, and Helsen (1989) explain competitive reaction to new entry in the airline and gynecological drug markets. They show that firms' reactions are a function of the elasticity of marketing mix variables. In the two oligopolistic markets studied, firms reacted positively with their most effective (elastic) marketing mix weapons and cut-back on their least effective (inelastic) weapons. However, their model did not examine the success of these reaction strategies.

Robertson and Gatignon (1991) provide managerially-focused generalizations as to conditions under which each marketing instrument should be used. With the assumption that, on average, firms use the most effective instrument given their competitive and market conditions, in practice we will observe a positive relationship between the intensity of reaction on any marketing instrument and the success of the reaction. 


\section{$H_{2 a} \quad$ Increases in advertising/salesforce/channel expenditures will be positively related to success of reaction. \\ $H_{2 b} \quad$ Reaction on the product dimension will be positively related to success of reaction. \\ $\mathrm{H}_{2 c} \quad$ Price decreases will be positively related to success of reaction.}

\subsubsection{Breadth of reaction. Will reaction on a range of marketing mix variables be more or}

less successful than reaction on a single variable? In line with Gatignon, Anderson and Helsen (1989), we expect firms to react on the marketing mix instrument with the highest elasticity. Since we also expect declining marginal effectiveness for each additional type of reaction, a firm is likely to react primarily along one or two dimensions. An increased number of reactions implies the use of less effective instruments. Given a fixed resource base, a large number of reactions implies insufficient weight behind each reaction. Thus, we hypothesize the following:

\section{$\mathrm{H}_{3}$ Breadth of reaction will be negatively related to success of reaction.}

Empirically, we are not aware that this proposition has been tested. In a somewhat different domain (reaction to price decreases) and with a different concern (predicting reaction), Heil, Morrison and Walters (1994) noted that firms reacting strongly (with important commitment of resources relative to capability and relative to industry practice) utilize a large number of variables. Although strength of reaction was the focus of their study (the dependent variable), the number of reaction variables employed appears as a distinct (even though possibly related) dimension of the defense strategy. Robinson (1988a) considered a similar construct: his "reaction index" is based on the number of marketing mix instruments used. Again, however, this measure was the dependent variable, rather than success of 
reaction as in the present research. Thus, there is precedent for the breadth of reaction variable but no empirical data that relates breadth to success of reaction.

The argument for the proposed negative relationship between breadth and success is that breadth is likely not to properly take into account varying marketing instrument elasticities. Indeed, the spread of resources across marketing variables would seem to dilute the overall reaction effect and to indicate a lack of focus. It is possible that a broad reaction strategy would be used in order to take advantage of all the means at hand to counter the entrant. This would be done in order to: (1) benefit from possible interactions or a multiplier effect among the marketing mix variables ${ }^{1},(2)$ prevent the entrant from using any other marketing mix instrument to react back and/or (3) send a non-equivocal signal of commitment and willingness to defend. However, it is our contention that such a broad reaction would be less effective than a narrow, focused, reaction.

\subsection{Product Category Characteristics}

\subsubsection{Product Category Growth. Regardless of the defense strategy pursued by the} incumbent, the success of the entrant and of the incumbent depends on the nature of the product category. High growth markets typically are considered to be attractive markets in which firms should have a propensity to invest. If a firm has already committed to such a market opportunity, it is unlikely that it will let new firms enter freely. This is especially true, since in such markets a shake-out typically occurs before the maturity stage. Consequently, competitors who want to survive have to establish and protect their position early in the product life cycle.

This retaliation strategy has a deterrence effect on new or potential entrants by limiting their ability to develop in the market and might encourage exit of the new entrant (depending 
on exit barriers). The result is to force an industry shake-out earlier than it would occur normally (i.e., without entry deterrence) so that the stronger competitors achieve greater concentration in the market. A case example is that of the artificial sweetener market in which Nutrasweet has aggressively cut price in the face of new competitive entry as its patents expire. The result has been the exit of at least two competitors from this market (Brandenburger 1993).

Robinson (1988a) found retaliation to be associated with high growth markets, as did Ramaswamy, Gatignon and Reibstein (1994), each using different PIMS data bases. Cubbin and Dombèrger (1988) is the only study, to our knowledge, which found a greater likelihood of retaliation and a greater extent of reaction in static markets. A rationale for a negative relationship between market growth and reaction is provided by Robinson (1988a) who argues that in expanding markets, firms tend to operate close to capacity. Consequently, they have little margin for reacting, which might involve the need for a higher capacity level (with the implication of investment in capacity expansion) and the need for additional financial resources to support the marketing retaliation effort. These resources are problematic given that resources tend to be constrained at early stages of the product life cycle. This reasoning, therefore, argues for little reaction of any kind in high growth markets. However, most of the empirical work fails to support this thesis. As reported above, studies which consider multiple marketing response instruments (as opposed to Cubbin and Domberger which analyzes only advertising rivalry), report a greater reaction in high growth markets, as well as a quicker response (Bowman and Gatignon 1995).

The reader will note that the empirical research base to date has focused on the likelihood of reaction in high growth markets and not the success of reaction. However, the literature provides a rationale for explaining success of reaction. Firms encountering a high 
growth market might be able to gain a position in market niches or segments without affecting the sales and growth of the incumbents because of the high potential in developing a new market which is often not yet segmented. This ease of entry in high growth markets has been evoked in the marketing strategy literature (Aaker and Day 1985). This theory has been contested by Day (1986) who argues that incumbents, even in high growth markets, develop expectations, and when these expectations are not met because of a new entrant, reactions can be strong (Ramaswamy, Gatignon, and Reibstein 1994). However, even under these conditions, the entrant will not affect the incumbent to the same extent as it would in a low growth market. Regardless of the defense strategy used by the incumbent, the new entrant does not hurt the incumbent as much in a high-growth market as in a low-growth market. Therefore, we propose that:

\section{$\mathrm{H}_{4}$ Product category growth rate will be positively related to success of reaction.}

\subsubsection{Technological Intensity. The shortening of product life cycles has been documented} across a range of product categories as disparate as cosmetics, foods, toys, pharmaceuticals, and computers (von Braun 1990), although Bayus (1992) has offered contrary evidence in the home appliance industry. Relatedly, the firm's portfolio of sales has changed such that volume is increasingly generated from products on the market for a shorter period of time. Von Braun (1990), who was Head of Technology Strategy for Siemens, provided evidence that in $1975,40 \%$ of Siemens' sales were represented by products on the market less than six years and that by 1986 , this proportion had increased to $56 \%$ of sales.

In product categories characterized by a high level of technological intensity, product reactions will be more difficult. Higher levels of technological intensity create a "gateway to entry" (Yip 1982) because new entrants have the ability to use the latest or lower cost 
technology to leapfrog. An incumbent monopolist may not be amenable to this new technology, since innovation destroys rents in the firm's existing products (Scherer and Ross 1990). For example, incumbents may seek to maintain backward compatibility with earlier technologies, even at the cost of a lower level of innovation. Given the shorter product life cycles of high technology product categories, the time to regain sales momentum is also constrained (Von Braun 1990). It is our expectation, therefore, that success of reaction will be lower under conditions of technological intensity.

\section{$H_{s}$ Technological intensity will be negatively related to success of reaction.}

\subsection{Competitive Threat}

\subsubsection{Incumbent's Relative Marketing Advantage. The management and marketing strategy}

literatures recently have accentuated the notion of core competencies or capabilities (Prahalad and Hamel 1990; Day 1994). We should note that the current specification of this form of relative competitive advantage has a rich legacy in alternative but highly similar specifications of the firm's capabilities, such as Selznick's (1957) concept of distinctive competencies or Teece's (1986) notion of complementary assets.

The capabilities approach focuses attention on the distinctive, hard-to-duplicate resources that the firm has developed over time. Prahalad and Hamel (1990) discuss institutionalized capabilities which differentiate the firm strategically, such as investments in collective learning and the ability to harmonize streams of technology. These capabilities represent a form of entry barrier that potentially limits the success of new entrants. We would be remiss, however, if we did not indicate that the reverse of core competencies is "core rigidities" (Leonard-Barton 1992). Firms may pursue a particular set of capabilities that can lead to "incumbent inertia," which retards the receptivity to new ways of conducting business 
- whether new technologies or new marketing systems. IBM, for example, may be a classic case of incumbent inertia; its core competencies in mainframes resulted in late market entry in PCs and workstations, and its core competencies in direct sales resulted in late endorsement of alternative sales channels, such as the catalog and telemarketing channels pioneered by Dell or the mass merchant channels pioneered by Packard-Bell.

It is on marketing capability that we focus here because of our emphasis on the incumbent's capability to mount a successful market defense. The proposition is that strong capabilities in customer relationships, channel access and brand reputation will limit the success of any new entrant.

\section{$H_{6}$ The incumbent's level of marketing advantage will be positively related to success of reaction.}

1.3.2. New Competitor's Relative Price. The relationship of price to reaction success requires little justification. It is our expectation that the lower the relative price level of the new entry, the less successful will be the competitive defense, ceteris paribus. Thus:

\section{$H_{7}$ The new entry's level of relative price advantage will be negatively associated with success of reaction.}

\subsubsection{Relative Innovativeness of New Entry. Product design in many industries follows a} pattern of stability punctuated by discontinuities or radical innovations. During these periods of stability (Landau 1984), firms may introduce a series of product enhancements or technology migrations. The introduction of reasonably continuous innovations would seem to favor the probability of successful defense by incumbent firms, particularly if a dominant design has been established (Teece 1986), although adherence to dominant designs may put the firm at risk (Ghemawat 1991). Indeed, Anderson and Tushman (1990) have documented that incumbent firms tend to champion technologies which are "competence enhancing." 
At the other extreme incumbents may be faced by innovative entry by newcomers which champion designs that are "competence destroying" (Anderson and Tushman 1990). For example, biotechnology is not compatible with the existing R\&D core competencies of pharmaceutical firms (Pisano 1990), and innovation has come from newcomers rather than pharmaceutical industry incumbents. Interestingly, the downstream competencies of these pharmaceutical firms are still formidable and biotech firms have tended to utilize their sales/marketing resources by licensing and co-venturing. Ettlie, Bridges and O'Keefe (1984) have shown that unique strategy and structure are necessary for radical innovation, whereas more traditional strategy and structure support incremental innovation. It is in these cases of discontinuous innovation that the incumbent firm is least likely to be able to defend its market position.

\section{$H_{8}$ The new entrant's relative innovativeness will be negatively associated with the incumbent's success of reaction.}

\section{Methodology}

\subsection{Data}

The data used to test the hypotheses come from a large scale survey of marketing executives across a range of industries in the U.S.A. We mailed a questionnaire to a sample of two thousand executives in June 1993 obtained from a commercial list of marketing executives. A financial incentive (the drawing of a $\$ 500$ prize) was included. A reminder mailing was made two weeks after the initial one. A total of 416 questionnaires was returned, representing a $21 \%$ response rate among potential respondents. This response rate is comparable to other similar large scale surveys of executives and managers (Achrol and Stern 1988; Anderson, Chu, and Weitz 1987; Heide and John 1988; Gatignon and Robertson 1989; Robertson, Rymon and Eliashberg 1995). 
The survey elicited information about the presence and characteristics of a new product introduced by a competitor into the respondent's main product category. Since our study focuses exchusively on post-entry defense strategies, respondents who indicated that they could not remember a new product from a competitor were asked to return their incomplete surveys. Thirteen percent of the sample ( 55 respondents) indicated that they could not recall a new entrant and 15 questionnaires had missing data, thus providing 346 complete surveys. An analysis of the time since the competitor's new product had entered the market did not reveal significant differences ( $92 \%$ of the sample reported on events which occurred less than two years before).

We evaluated nonresponse bias by comparing the industries represented in our sample with the list utilized. No significant differences were found in the industries represented. We also compared early respondents (first half) with late respondents (second half), following Armstrong and Overton's (1977) procedure. No significant differences were found on key characteristics such as respondent industry, total company sales, or order of incumbent market entry, suggesting that nonresponse bias may not be a substantial problem.

Our data have a number of distinct advantages over other multi-industry data sets that have been used to study competitive reactions to market entry. Because we surveyed incumbents reacting to entry, the data capture information about both successful and unsuccessful entrants, limiting entrant survivor bias (Golder and Tellis 1993). Any remaining bias due to incumbent exit is likely to be limited. The data also capture reactions that may not have been perceived by the entrant, since we are taking the incumbent's perspective. In addition, many previous studies of competitive reactions have focused on a single industry (e.g., Smith, Grimm, Chen, and Gannon 1991). Our sample is reasonably representative of a wide range of industries, as shown in Table 2. 


\subsection{Measures}

The measures for the study are reported in Table 3. All but two of the constructs were assessed by multi-item measures. All items were measured using six point Likert scales, usually anchored by "strongly disagree" and "strongly agree." Factor analysis indicated that the items in each scale loaded strongly on a single factor. The reliabilities are high, as indicated by the coefficient alpha of all the scales reported in Table 3 (all coefficients are higher than 0.79).

2.2.1. Speed of Reaction (reliability $=0.908$ ) captures the respondent's perception of the firm's reaction time in responding to the new entry. This measure permits comparison across a wide variety of market circumstances, unlike a measure such as actual calendar time until reaction. For example, a two month reaction time may be considered slow in the consumer packaged goods market but very fast in the chemical industry.

2.2.2. Marketing Mix Reaction. Reactions to entry were assessed along seven dimensions. Respondents were asked whether their firm responded on each of seven different marketing instruments. If they answered "yes," the respondent then indicated the level of response on a six point Likert scale anchored by "minor response" and "major response." Intensity within each reaction instrument was coded as 0 if no reaction took place and as the scale value (1-6) if the incumbent reacted on that instrument. Thus, reaction intensities ranged from $0-6$ for each of seven types of reaction to entry.

The seven dimensions of response were grouped into three different types of reactions. The intensity levels were summed to obtain combined reaction intensity scales. Advertising/Salesforce/ Channel Reaction Intensity measures the combined intensity of three reactions: increasing the advertising and promotion budget, expanding the salesforce, and 
expanding distribution. Product Reaction Intensity measures the combined intensity of three reactions: improving the existing product, repositioning the existing product, or introducing a new product. Price Decrease Intensity measures the single reaction of a price decrease in response to the competitive entry.

2.2.3. Breadth of Reaction. This variable, similar to Robinson's (1988a) "reaction index," is the combined number of marketing mix instruments used to react. Its range is from zero to seven reaction instruments.

2.2.4. Success of defense (reliability $=0.821$ ) measures the perceived performance of the incumbent following the new competitive entrant. Although self-assessment measures are prone to potential bias, they are the most commonly used form of performance assessment in marketing strategy research (Saunders, Brown and Laverick 1992). Their use has been justified by a number of reasons. First, it is recognized that the presumably more "objective" financial measures and sources can be biased as well "because of the ulterior motives for which they are produced" (Saunders, Brown and Laverick 1992, p.184). Secondly, objective financial data are generally available at the aggregate firm level and not at the level of the product category where the research is focused. Thirdly, it may be asserted that managers have the greatest knowledge of their own performance. Finally, self-assessed measures have been shown to be reliable (Doyle, Saunders and Wright 1989, Dess and Robinson 1984, Venkatraman and Ramanujam 1986). The items in our measures directly link the entry with the incumbent's subsequent market performance. This provides a level of confidence that changes in market position unrelated to the new entrant are not spuriously correlated with the characteristics of the new competitor.

2.2.5. Product Category Characteristics. In our conceptualization, product category variables influence the success of reaction. Growth measures the category growth rate and stage of the 
product life cycle (reliability $=0.799$ ). Level of Technology is a 3-item measure of the importance of technology within the product category (reliability $=0.838$ ).

2.2.6. Competitive Threat. Three separate measures captured the competitive threat posed by the new entrant. Incumbent's Relative Marketing Advantage reflects competitive differentiation in underlying organizational marketing capabilities between the incumbent and the entrant. The capabilities included in the measure are intended to be distinctive, imperfectly mobile, and hard to imitate. These type of capabilities can be potent sources of sustained competitive advantage (Barney 1991). Relative Price vs. New Competitor gauges the new entrant's attempt to compete with the incumbent on price. Relative Innovativeness of New Competitor vs. Incumbent measures the advantage of the new competitor's product.

Therefore, the items characterize the degree to which the new product represented a substantial change in underlying technology or in value to consumers, forming a scale with a reliability of 0.866 .

\subsection{Model}

The success of defense measure is regressed on the variables hypothesized to influence

it. The following model was, therefore, estimated:

$$
\begin{gathered}
\text { SUCCESS }_{i}=\beta_{0}+\beta_{1} \text { SPEED }_{i}+\beta_{2} \text { MRTGINT }_{i}+\beta_{5} \text { PRODINT }_{i}+\beta_{4} \text { PRICINT }_{i}+\beta_{5} \text { BREADTH }_{i}+\beta_{6} \text { GROWTH }_{i} \\
+\beta_{7} \text { TECH }_{i}+\beta_{8} \text { RELCA }_{i}+\beta_{9} \text { RELPRICE }_{i}+\beta_{10} \text { NPINNOV }_{i}+v_{i}
\end{gathered}
$$

where:

$\begin{array}{lll}\text { SUCCESS }_{i} & = & \text { Perceived performance of the incumbent respondent } i \\ \text { SPEED }_{i} & = & \text { Speed of response, } \\ \text { MKTGINT }_{i} & = & \text { Intensity of communication response, } \\ \text { PRODINT }_{i} & = & \text { Intensity of response with product mix } \\ \text { PRICNNT }_{i} & = & \text { Intensity of price decrease, } \\ \text { BREADTH }_{i} & = & \text { Breadth of reactions of respondent } i \\ \text { GROWTH }_{i} & = & \text { Growth of market for incumbent respondent } i, \\ \text { TECH }_{i} & = & \text { Level of technology in product category, }\end{array}$




\begin{tabular}{|c|c|c|}
\hline $\begin{array}{l}\text { RELCA }_{i} \\
\text { RELPRICE. }\end{array}$ & $=$ & $\begin{array}{l}\text { Competitive advantage of incumbent relative to new entry, } \\
\text { Relative price of incumbent versus new entrv }\end{array}$ \\
\hline NPDNNOV $_{\mathrm{i}}$ & $=$ & $\begin{array}{l}\text { Innovativeness of new product relative to incumbent } \\
\text { Disturbance term }\end{array}$ \\
\hline
\end{tabular}

This model was estimated using Ordinary Least Squares. The structural model parameters were also estimated with an analysis of covariance structure performed with LISREL8 in order to take into account the errors in measurement which could potentially bias the OLS parameter estimates. The estimated parameters have the same signs and the same magnitudes. This similarity of results is due to the limited potential for bias when the measures are highly reliable. Therefore, the OLS results are reported and discussed below.

\subsection{Results}

We find that reactions to new products by incumbents are quite common. $90 \%$ of the incumbents in our sample reacted in some way to the new entrant: $56 \%$ of the sample made a "communication" reaction via advertising, salesforce, or channel, $27 \%$ cut price and $82 \%$ reacted by changing the product or by introducing a new one. These results can be contrasted with previous research on reaction frequency when an incumbent is faced with a new product entry. For example, Biggadike (1979) and Robinson (1988a) both found that a lack of reaction is the norm. Robinson (1988a) reports that $91 \%$ of incumbents from the Strategic Planning Institute's start-up business database did not react in the first year following new business entry and $82 \%$ did not react in the second year. However, Bowman and Gatignon (1995) found that $60 \%$ of competitors in the PIMS SPIYR database did react when faced with a new product introduction, as opposed to a new firm entering the market. They suggest that reactions to new product entries are more common than reactions to start-up businesses 
because of the inherent uncertainty associated with start-up businesses which reduces the incumbent's propensity to react.

The somewhat larger percentage of firms which reacted in the present study can be due to both our more detailed measurement of reaction and to the fact that we surveyed incumbents reacting to entry, limiting any entrant survivor bias that may be present in the PIMS database. In a different domain, Heil, Morrison and Walters (1994) have documented that $95 \%$ of firms respond in some way when confronted with price reductions. This level of response is highly comparable to what we found among firms confronted with new competitive products.

In addition, it is interesting to note that $17 \%$ of the sample responded with all three marketing mix variables, $49 \%$ used a combination of communication and product mix responses, $25 \%$ used a combination of product mix and price responses, and $18 \%$ responded both with a communication variable and with a price decrease.

The parameter estimates of equation (1) are provided in Table 4. The final analysis is performed on data from 346 usable questionnaires. Ten outliers were then identified and eliminated based on their residual values. The exclusion of these observations does not change any of the results but provides a slightly better fit of the model: The $F$ test indicates that the 10 outliers are generated by the same model as the one estimated from the 336 observations $\left(\mathrm{F}\left(v 1,=10, v_{2}=325\right)=.008\right)$.

Most of the variables hypothesized to affect the perceived success of a defense strategy are significant at the 0.01 significance level. However, the percentage of explained variance in the model is moderate with a value of $0.31 .^{2}$ An examination of the residuals did not show any sign of heteroscedasticity and the pattern appears to be random noise. This indicates that the data are consistent with the conceptual framework which we have developed. 
2.4.1. Reaction Strategy. As expected, the speed of response by the incumbent is a strong predictor of the success of the reaction strategy $(\beta=0.121, t=2.64)$. The value of the speed of reaction which is alluded to in the management literature is highly supported by this broad cross-sectional study of incumbents confronted by new product entry.

As hypothesized, increases in advertising/salesforce/channel expenditures are positively associated with the success of the reaction strategy $(\beta=0.044, t=3.17)$. Similarly, the stronger the reaction on the product dimension, the more successful is the perceived defense strategy $(\beta=0.048, t=3.75)$. In fact, the effect of reaction by either of these marketing mix variables is similar, as indicated by a test of equality of the two coefficients. $\left(F\left(v_{1}=1, v_{2}=\right.\right.$ $325)=0.076)$.

Contrary to our expectation, however, price decreases are not positively related to the success of the reaction. In fact, there is a negative (but nonsignificant) tendency which suggests that lowering price is associated with less reaction success. It may very well be that lowering price is a default option when the incumbent is unable to cope with the innovativeness of the new product entry. Of course, failing to have cut price might have resulted in a worse situation.

The breadth of reaction, as hypothesized, is shown to be related negatively to the perceived success of the defense strategy $(\beta=-0.228 t=-5.02)$. That is, firms which react on multiple marketing mix instruments report less successful defenses. This might be because the effect of reaction is being dihuted by spreading resources over multiple marketing mix instruments. The firm may not be optimizing response based on a sound examination of marketing mix elasticities for each instrument.

2.4.2. Product Category Characteristics. Variables characterizing the product category in our model include market growth and level of technology. We hypothesized that a new entrant 
tends to be perceived as less of a threat and, therefore, the incumbent will be perceived to be more successful in defending its position in a fast growing market than in a slow growing market. This hypothesis is supported by the data $(\beta=0.113, \mathrm{t}=2.31)$. This is consistent with the role of market growth found in previous strategy research. The results also indicate that in industries that are more technological, incumbents perceived that defending market position is less successful $(\beta=-0.157, t=-3.57)$. This confirms our hypothesis that there will be less success in responding to a new entry in highly technological markets.

2.4.3. Competitive Threat. It is expected that the level of the competitive threat variables will have a strong impact on the perceived success of the reaction. It is important to control for these effects since these variables are somewhat correlated with the defensive strategy used by the incumbents. Therefore, omitting these variables would bias the estimates of the impact of the defense strategy. These effects indicate the extent to which an incumbent is directly perceived to be hurt by a new entry, before, or regardless of, any reaction by the incumbent.

As expected, the extent of the threat of the new entry directly affects the perceived success of the reaction. The three measures of competitive threat are statistically significant. The greater the incumbent's relative marketing advantage, the more successful the incumbent is in defending its position $(\beta=0.123, t=2.62)$. An innovative entry has a negative impact on the perceived performance of the incumbent $(\beta=-0.259, t=-5.84)$. The higher the price of the incumbent relative to the new entry at the time of introduction, the worse the performance of the incumbent $(\beta=-0.084, t=-2.34)$. This indicates that in the absence of a reaction from the incumbent, the greater the competitive threat, the more the incumbent's performance is hurt.

\section{Conclusion and Discussion}




\subsection{Intended Contribution}

This study brings new information to academics and managers concerning the impact of an incumbent's defense strategy when faced with a new product entry in the market. We make inferences from a large cross section of firms, which we believe contributes to the generalizability of the results.

This study seeks to add to the extant literature on market defense in multiple ways:

- We make inferences as to the success of reaction strategies, rather than the likelihood of reactions.

- We do not focus our attention on a single key element of the reaction strategy. Instead, we investigate the impact of the speed of the reaction, the impact of the marketing mix instrument (communication, price, product) used to react, as well as the impact of the breadth of the reaction.

- Our measure of the success of a reaction strategy is based on the perceived market performance of the incumbent after making the response. We consider perceived performance in order to accommodate differences in industries in a large-scale study involving a cross-sectional analysis.

- This study is differentiated from most of the existing research in this area because it is based on the analysis of survey data. The only empirical literature in marketing on defense to new entry involving cross-sectional data is based on the PIMS database. The remaining empirical work on defense is limited to single industry studies.

- While the existing literature often deals with new entrants, we focus on new products. 
- The existing literature does not distinguish whether the new entry is a continuous or discontinuous innovation. In our study, we measure and control for the degree of innovativeness of the new product.

These distinguishing features between our study and the existing literature enable us to draw a number of managerial conclusions which would seem to transcend specific industries. ${ }^{3}$

\subsection{Limitations}

Although we explicitly selected a survey methodology, there are inherent limitations to surveys. A first issue is that of non-response and whether bias exists as a result. It may be that managers who are most likely to respond are somewhat more sensitized to competitive signals and competitive interplay. In the present case our response rate is reasonable relative to other surveys with managers and our analysis of early versus late responses suggests limited potential for non-response bias.

Although we control for market characteristics, we cannot model the impact of the responses of all the competitors, since we only have information about the actions of a single incumbent in every market. This might affect the perceived performance of the incumbent being analyzed, especially in markets which become more competitive as a result of the entry. In markets which were already competitive before the entry, management would probably incorporate these expectations in their assessment of perceived performance.

It is also possible that incumbents operating in crowded markets may be unaware of late entrants or the details of their entry strategies. However, this does not seem to be the case in our sample because the respondent's degree of involvement with the response strategy does not differ depending on the number of competitors in the market. Our research also relies on a key informant data source. Although it is possible that multiple respondents within the firm 
more fully represent the decision process, this incurs a high cost. Respondents were asked their degree of involvement in the decision of how to respond to the competitor's new product. The mean level of involvement was 1.58 ( 4 point scale, " $1=$ Highly involved $/ 4=$ Not involved"), indicating that knowledge about the reaction decision and the new entrant's strategy was good.

Furthermore, we use self-report measures of the success of defense. Although we have argued in favor of such measures and although objective measures are difficult to derive, it would be desirable to compare both subjective and objective success indicators.

The explanation of success of defense is provided by a number of structural factors, as demonstrated by the significance of the coefficients in our model. Nevertheless, the explanatory power is not as high as would be desired $\left(R^{2}=.31\right)$. Future research should investigate other factors that can improve the percentage of explained variance. We did test interactions between the reaction strategy and structural characteristics of the market and of the incumbent without significant results. This indicates that the effectiveness of the reaction strategy does not depend on these structural factors. Effectiveness might depend more on the firm's intrinsic characteristics, which would be independent of the structural factors addressed in this study.

\subsection{Management Implications}

How should managers react when faced with a new product entry? Our findings suggest some major implications. First, response should occur quickly. The data strongly suggest that the perceived success of the incumbent's reaction strategy increases with the speed of response. Second, response should occur on as few marketing mix instruments as possible. The greater the breadth of reaction, the less successful the reaction. Pursuing a 
range of reactions seems to dilute the effectiveness of reaction, perhaps by underspending on each marketing mix instrument relative to its marginal utility.

As to which marketing mix instrument(s) to use, this depends on the elasticity of each imstrument for a particular firm at a particular time. However, responses on advertising/salesforce/channels and on the product mix can all be successful. By contrast, price reductions are not associated with successful defense strategies. Lowering price may be a sign of weakness when the firm is unable to make other responses. Of course, it may also be that the results for these firms would have been even less favorable if they had not lowered price. This is especially true when the new product has a lower price than the incumbent, since a price differential is then detrimental to the incumbent.

The incumbent's relative marketing advantage provides a level of protection in defending against new product entry. Of course, this advantage would have to be built over time before being threatened by a new entry. The manager of an incumbent firm in a high growth market is also somewhat more likely to maintain success after a new product entry and when competing in a low technology product category. However, these are obviously factors beyond the individual manager's control.

It would appear, based on these results, that there is value in the current "time-based" approaches to management strategy. When confronted by a new product entry, it is recommended that managers move with dispatch and focus on a limited set of marketing mix variables. Success of reaction declines as a greater number of marketing instruments are utilized. The selection of a particular marketing mix instrument was not the subject of our analysis and different instruments can have positive effects, except for lower price which seems not to be associated with successful response. This would indicate that incumbents should avoid to respond price reactions after competitive entry. However, if they can 
anticipate the entry price, they should adjust their price to reduce the price differential at the time of entry. 


\section{ENDNOTES}

1. We thank a reviewer for suggesting this possibility.

2. The breadth variable is correlated with the intensity of a product response $(\rho=0.68)$, with the intensity of a communication response $(\rho=0.61)$ and to a lesser extent with the amount of price decrease $(p=0.41)$. However, this did not appear to cause multicollinearity problems, as revealed by the stability of the results and a reasonable $\mathbf{R}^{2}$.

3. We tested the contribution of industry dummy variables but found them to be insignificant. 


\section{REFERENCES}

Aaker, D. A. and G. S. Day, 1985. The Perils of High Growth Markets. Strategic Management Journal (October-December), 403-421.

Achrol, S. S. and L. W. Stern, 1988. Environmental Determinants of Decision-Making Uncertainty in Marketing Channels. Journal of Marketing Research 25, 1 (February), 36-50.

Anderson, E., W. Chu and B. Weitz, 1987. Industrial Purchasing: An Empirical Exploration of the Buyclass Framework. Journal of Marketing 51, 3, 71-86.

Anderson, P. and M. L. Tushman, 1990. Technological Discontinuities and Dominant Designs: A Cyclical Model of Technological Change. Administrative Science Quarterly 35, 604633.

Armstrong, J. S. and T. S. Overton, 1977. Estimating Nonresponse Bias in Mail Surveys. Journal of Marketing Research 14 (August), 396-402.

Bain, J., 1956. Barriers to Competition. Cambridge, MA: Harvard University Press.

Barney, J., 1991. Firm Resources and Sustained Competitive Advantage. Journal of Management 17, 1, 99-120.

Bayus, B. L., 1992. Have Diffusion Rates Been Accelerating Over Time? Marketing Letters 3 (3), 215-226.

Bazerman, M. H. and J. S. Carroll, 1987. Negotiator Cognition. In: B. M. Staw and L. L. Cummings (eds.), Research in Organizational Behavior, 247-288. Greenwich, CT: JAI Press.

Bettman, J. R, 1979. An Information Processing Theory of Consumer Choice. Reading, MA: Addison-Wesley.

Biggadike, R. E. (1979). Corporate Diversification: Entry, Strategy and Performance. Cambridge, MA: Harvard University Press.

Bowman, D. and H. Gatignon, 1995. Determinants of Competitor Response Time to a New Product Introduction. Journal of Marketing Research 32, 1 (February), 42-53.

Brandenburger, A., 1993. Bitter Competition: The Holland Sweetener Company Versus Nutrasweet. Case Study N9-794-079. Boston, MA: Harvard Business School.

Brown, W. B. and N. Karagozoglu, 1993. Leading the way to Faster New Product Development. Academy of Management Executive 7 (February), 36-47. 
Carpenter, G. S. and K. Nakamoto, 1983. Consumer Preference Formation and Pioneering Advantage. Journal of Marketing Research 26 (3), 285-298.

Caves, R E., 1984. Economic Analysis and the Quest for Competitive Advantage. Papers and Proceedings of the 96th Annual Meeting of the American Economic Association 74 (2), 127-132.

Caves, R. E. and M. E. Porter, 1977. From Entry Barriers to Mobility Barriers: Conjectural Decisions and Contrived Deterrence to New Competition. Quarterly Journal of Economics 91, (May), 241-262.

Chen, M. and I. C. MacMillan, 1992. Nonresponse and Delayed Response to Competitive Moves: The Roles of Competitor Dependence and Action Irreversibility. Academy of Management Journal 35, 3, 539-570.

Clark, K. B. and S. C. Wheelwright, 1993. Managing New Product and Process Development. New York: The Free Press.

Cohen, W. M. and R. C. Levin, 1989. Empirical Studies of Innovation and Market Structure. In: R Schmalensee and R. D. Willig (eds.), Handbook of Industrial Organization, Vol. 2, New York: Elsevier.

Cubbin J. and S. Domberger, 1988. Advertising and Post-Entry Oligopoly Behavior. The Journal of Industrial Economics 37, 2, 123-140.

Day, G. S., 1994. The Capabilities of Market-Driven Organizations. Working Paper. The Wharton School, University of Pennsylvania.

Day, G. S., 1986. Analysis for Strategic market Decision. St. Paul, MN: West Publishing Co.

Dess, G. S. and R. B. Robinson, 1984. Measuring Organisational Performance in the Absence of Objective Measures. Strategic Management Journal 5, 265-273.

Doyle, P., J. Saunders and L. Wright, 1989. A Comparative Study of US and Japanese Marketing Strategies in British Market. International Journal of Research in Marketing $5,3,171-184$.

Eisenhardt, K. M., 1990. Speed and Strategic Choice: How Managers Accelerate Decision Marking. California Management Review 32 (Fall), 1-16.

Ettlie, J. E., W. P. Bridges and R D. O'Keefe, 1984. Organization Strategy and Structural Differences for Radical Versus Incremental Innovation. Management Science 30 (June), 682-695.

Gatignon, H., E. Anderson and K Helsen, 1989. Competitive Reactions to Market Entry: Explaining Interfirm Differences. Journal of Marketing Research 26 (February), 44-55. 
Gatignon, H. and T. S. Robertson, 1989. Technology Diffusion: An Empirical Test of Competitive Effects. Journal of Marketing 53, 1 (January), 35-49.

Ghemawat, P., 1991. Market Incumbency and Technological Inertia. Marketing Science 10 (Spring), 161171.

Gilbert, R. J., 1992. Symposium on Compatability Incentives and Market Structure. Journal of Industrial Economics 40 (March), 1-8.

Golder, P. N. and G. J. Tellis, 1993. Pioneer Advantage: Marketing Logic or Marketing Legend. Journal of Marketing Research 30 (May), 158-170.

Hanssens, D. M., 1980. Market Response, Competitive Behavior and Time Series Analysis. Journal of Marketing Research 17 (November), 470-485.

Hauser, J. R, 1986. Theory and Application of Defensive Strategy. In: L. G. Thomas III (ed.), The' Economics of Strategic Planning, Lexington, MA: Lexington Books.

Hauser, J. R, 1988. Competitive Price and Positioning. Marketing Science 7, 1, 76-91.

Hauser, J. R. and S. P. Gaskin, 1984. Application of the DEFENDER consumer model. Marketing Science 3, 4, 327-351.

Hauser, J. R. and S. M. Shugan, 1983. Defensive Marketing Strategies. Marketing Science 2 (Fall), 319-360.

Heide, J. B. and G. John, 1988. The Role of Dependence Balancing in Safeguarding Transaction-Specific Assets in Conventional Channels. Journal of Marketing 52 (January), 20-35.

Heil, O. P., D. G. Morrison and R. G. Walters, 1994. Explaining the Strength of Competitive Reactions to Price Reductions. A Working Paper. UCLA Anderson School of Management.

Heil, O. and T. S. Robertson, 1991. Toward a Theory of Competitive Market Signaling: A Research Agenda. Strategic Management Journal 12, 403-418.

Huff, L. C. and W. T. Robinson, 1992. The Impact of the Market Pioneer's Leadtime on Market Share. Working Paper. School of Business Administration, University of Michigan.

Kumar, K. R and D. Sudharshan, 1988. Defensive Marketing Strategies: An Equilibrium Analysis Based on Decoupled Response Function Models. Management Science 34, 7, 805-815.

Lambin, J.J., P. A. Naert and A. Bultez, 1975. Optimal Marketing Behavior in Oligopoly. European Economic Review 6, 105-128. 
Lambkin, M., 1988. Order of Entry and Performance in New Market. Strategic Management Journal 9, 127-140.

Landau, R, 1984. The Nature of Technological Knowledge. Boston: Reidel.

Leeflang, P. S. H. and D. R. Wittink, 1992. Diagnosing Competitive Reactions Using (aggregated) Scanner Data. International Journal of Research in Marketing 9, 39-57.

Leonard-Barton, D., 1992. Core Capabilities and Core Rigidities: A Paradox in Managing New Product Development. Strategic Management Journal 13, 111-125.

Milgrom, P. and J. Roberts, 1982. Limit Pricing and Entry Under Incomplete Information: An Equilibrium Analysis. Econometrica 50 (March), 443-459.

Millson, M. R, S. P. Raj and D. Wilemon, 1992. A Survey of Major Approaches for Accelerating New Product Development. Journal of Product Innovation Management 9, 53-69.

Pisano, G. P., 1990. The R\&D Boundaries of the Firm: An Empirical Analysis. Administrative Science Quarterly 35 (March), 153-176.

Porter, M. E., 1980. Competitive Strategy: Techniques for Analyzing Industries and Competitors. New York: The Free Press.

Porter, M. E., 1985. Competitive Advantage: Creating and Sustaining Superior Performance. New York: The Free Press.

Prahalad, C. K and G. Hamel, 1990. The Core Competence of the Corporation. Harvard Business Review 68 (May-June), 79-91.

Ramaswamy, V., H. Gatignon, and D. J. Reibstein, 1994. Competitive Marketing Behavior in Industrial Markets. Journal of Marketing, 58 (April), 45-55.

Robertson, T. S., 1993. How to Reduce Market Penetration Cycle Times. Sloan Management Review 35 (Fall), 87-96.

and H. Gatignon, 1991. How Innovators Thwart New Entrants Into Their Market. Planning Review 19, September-October, 4-11 and 48.

, T. Rymon and J. Eliashberg, 1995. NPA Signals and Incumbent Reactions. Journal of Marketing 59 (July), forthcoming.

Robinson, W. T., 1988a. Marketing Mix Reactions to Entry. Marketing Science 7 (Fall), 368385.

,1988b. Sources of Market Pioneer Advantages: The Case of Industrial Goods Industries. Joumal of Marketing Research 25 (February), 87-94. 
and C. Fornell, 1985. Sources of Market Pioneer Advantages in Consumer Goods Industries. Journal of Marketing Research 22 (August), 305-317.

Saunders, John, Michael Brown and Stuart Laverick, 1992. Research Notes on the Best British Companies: A Peer Evaluation of Britain's Leading Firms. British Journal of Management 3, 181-195.

Scherer, F. M. and D. Ross, 1990. Industrial Market Structure and Economic Performance. Boston: Houghton Mifflin Company.

Sellars, P., 1994. MCI Communications: Yes, Brands Can Still Work Magic. Fortune 129, 3 (February 7), 133-134.

Selznick, P., 1957. Leadership in Administration. New York: Harper \& Row.

Smith, K G., C. M. Grimm, M. Chen and M. J. Gannon, 1991. Predictors of Response Time to Competitive Strategic Actions: Preliminary Theory and Evidence. Journal of Business Research 18, 245-258.

Smith, K. G., C. M. Grimm, M. J. Gannon and M. Chen, 1991. Organizational Information Processing, Competitive Responses, and Performance in the U.S. Domestic Airline Industry. Academy of Management Journal 34, 1, 60-85.

Smith P. E. and D. G. Reinertsen, 1991. Developing Products in Half the Time. New York: Van Nostrand Reinhold.

Stalk, G. Jr., 1988. Time: The Next Source of Competitive Advantage. Harvard Business Review (July-August), 41-51.

Teece, D. J., 1986. Profiting from Technological Innovation: Implications for Integration, Collaboration, Licensing and Public Policy. Research Policy 15, 228-305.

Tushman, M. L. and R. R. Nelson, 1990. Introduction: Technology, Organizations and Innovation. Administrative Science Quarterly 35, 1-8.

Urban, G. L., T. Carter, S. Gaskin and Z. Mucha, 1986. Market Share Rewards to Pioneering Brands: An Empirical Analysis and Strategic Implications. Management Science 32 (June), 645-659.

Vessey, J. T., 1991. The New Competitors: They Think In Terms of 'Speed to Market'. Academy of Management Executive 5, 2, 23-33.

Venkatraman, N. and Ramanujam, V., 1986. Measurement of Business Performance in Strategic Research: A Comparison of Approaches. Academy of Management Review $11,4,801-814$.

Von Braun, C., 1990. The Acceleration Trap. Sloan Management Review 49 (Fall), 49-58. 
Yip, G. S., 1982. Barriers to Entry. Lexington, MA: Lexington Books. 


\section{TABLE 1}

\section{Hypotheses}

\begin{tabular}{|c|c|}
\hline \multicolumn{1}{|c|}{ Variable } & $\begin{array}{c}\text { Relationship to } \\
\text { Success of Defense }\end{array}$ \\
\hline A. Response Variables & + \\
1. Incumbent's Speed of Response & + \\
2. Marketing Mix Response \\
- Advertising/Salesforce/Chann \\
el Reaction Intensity \\
- Product Reaction Intensity \\
3. Price Decrease Intensity \\
B. Industry Characteristics \\
- Product Category Growth Level \\
Technological Intensity \\
C. Competitive Threat \\
- Incumbent's Relative Marketing \\
Advantage \\
New Competitor's Relative Price \\
Advantage \\
New Competitor's Relative \\
Innovativeness
\end{tabular}




\section{TABLE 2}

\begin{tabular}{|l|r|r|}
\hline \multicolumn{3}{|c|}{ Distribution of Industries Represented in Sample } \\
\hline \multicolumn{1}{|c|}{ Industry } & $\mathrm{N}$ & $\begin{array}{c}\% \text { of } \\
\text { Sample }\end{array}$ \\
\hline Business Equipment & 38 & $11 \%$ \\
Business Supplies & 35 & $10 \%$ \\
Chemicals & 22 & $6 \%$ \\
Cosmetics and Toiletries & 8 & $2 \%$ \\
Electrical & 9 & $3 \%$ \\
Food and Beverage & 60 & $17 \%$ \\
Health & 41 & $12 \%$ \\
Household Products & 35 & $10 \%$ \\
Industrial Equipment & 63 & $18 \%$ \\
Packaging and Containers & 12 & $3 \%$ \\
Miscellaneous & 23 & $7 \%$ \\
Total Sample & 346 & $100 \%$ \\
\hline
\end{tabular}




\section{Measures and Reliability}

SUCCESS OF DEFENSE (alpha $=0.821$ ) ( $1=$ strongly disagree; $6=$ strongly agree)

Our sales are down since the competitor's new product entry. (reversed)

We have not been affected by the competitor's new product.

We have maintained almost all our market share.

We have lost momentum in this product category. (reversed)

If we had to do it again, we would have responded very differently. (reversed)

SPEED OF RESPONSE (alpha $=0.908$ ) ( 1 = strongly disagree; $6=$ strongly agree)

We made a very quick response.

We decided to wait and see what would happen. (reversed)

We made an immediate response. (reversed)

We thought it best to delay any reaction. (reversed)

We decided that it was best to live and let live. (reversed)

We reacted slowly and cautiously. (reversed)

MARKETING MIX RESPONSE (Yes $/$ No and $1=$ minor; $6=$ major)

Advertising/Salesforce/Channels Reaction Intensity

We increased our advertising and promotion budget.

We expanded our salesforce.

We expanded our distribution.

Product Reaction Intensity

We introduced a new product.

We improved our existing product.

We repositioned our existing product.

\section{Price Decrease Intensity}

We decreased our price

\section{BREADTH OF RESPONSE}

The combined number of marketing mix instruments used to react (Range $=0$ to 7 )

PRODUCT CATEGORY GROWTH (alpha $=0.799)(1=$ strongly disagree; $6=$ strongly agree)

This is a fast growing product category.

This product category is reaching maturity. (reversed)

This product category has been on the market for many years. (reversed)

This product category is at the decline stage of the product life cycle. (reversed)

TECHNOLOGICAL INTENSITY (alpha $=0.838)(1=$ strongly disagree; $6=$ strongly agree $)$

This is a high technology product category.

Technology dominates this product category.

Technology is not important in this product category. (reversed) 


\section{Measures and Reliability}

INCUMBENT'S RELATTVE MARKETING ADVANTAGE ( 1 = major competitive disadvantage; 6 = major competitive advantage)

Please tell us whether your firm has a competitive advantage on each capability vs. the new product entry.

Customer relationship

Marketing skills

Access to channels of distribution

Brand reputation

Service capability

NEW COMPETTTOR'S RELATIVE PRICE (alpha $=$ n.a.) $(1=$ strongly disagree; 6 = strongly agree)

The competitor's new product is priced lower than ours.

NEW COMPETTTOR'S RELATIVE INNOVATIVENESS (alpha $=0.866)(1=$ strongly disagree; $6=$ strongly agree)

The competitor's new technology was a substantial change in technology.

The competitor's new product was a "me too" innovation. (reversed)

Customers saw the competitor's new product as a major innovation in the product category.

The competitor's new product added significance customer benefits. 
TABLE 4

\begin{tabular}{|l|c|c|}
\hline \multicolumn{2}{|c|}{ Parameter Estimates } \\
\hline \multicolumn{1}{|c|}{ Variable } & Parameter Estimate & t-statistic \\
\hline Intercept & $2.417^{\mathrm{a}}$ & 13.42 \\
Speed of Response & $0.121^{\mathrm{a}}$ & 2.64 \\
Advertising/Salesforce/Channel Reaction Intensity & $0.044^{\mathrm{a}}$ & 3.17 \\
Product Reaction Intensity & $0.048^{\mathrm{a}}$ & 3.75 \\
Price Decrease Reaction Intensity & -0.042 & -1.54 \\
Breadth of Response & $-0.228^{\mathrm{a}}$ & -5.02 \\
& & \\
Product Category Growth & $0.113^{\mathrm{a}}$ & 2.31 \\
Technological Intensity & $-0.157^{\mathrm{a}}$ & -3.57 \\
& & \\
Incumbent's Relative Marketing Advantage & $0.123^{\mathrm{a}}$ & 2.62 \\
New Competitor's Relative Price Advantage & $-0.084^{\mathrm{a}}$ & -2.34 \\
New Competitor's Relative Innovativeness & $-0.259^{\mathrm{a}}$ & -5.84 \\
\hline
\end{tabular}

$$
\begin{aligned}
& N=336 \\
& \mathrm{R}^{2}=0.31 \\
& \mathrm{~F}=14.74 \\
& \mathrm{a}=\text { Parameter estimate is statistically significant at the } .01 \text { level. }
\end{aligned}
$$

